DOI https://doi.org/10.30525/978-9934-26-040-7-44

\title{
ІНФРАСТРУКТУРА ВІДКРИТИХ ДАНИХ ЯК ІНСТРУМЕНТ ЗАБЕЗПЕЧЕННЯ ПРАВА ОСОБИ НА ВИКОРИСТАННЯ ТА ДОСТУП ДО ПУБЛІЧНОЇ ІНФОРМАЦІЇ У ФОРМІ ВІДКРИТИХ ДАНИХ
}

\author{
Нестерова Д. В. \\ аспірантка кафедри інтелектуальної власності \\ та інформаційного права \\ Інституту права \\ Київського начіонального університету імені Тараса Шевченка \\ м. Київ, Украӥна
}

У сучасних умовах розвитку інформаційного суспільства дотримання права особи на доступ до публічної інформації значною мірою залежить від створення та налагодження ефективно функціонуючого механізму реалізації нормативно закріплених правил. Зрозумілим $\epsilon$ те, що такий механізм складається не лише з масивів даних, організацій, які їх експлуатують та підтримують, а також з процесів, політик та інструкцій, що описують використання та управління даними, відповідно це все формує інфраструктуру відкритих даних.

Актуальність питання інфраструктури відкритих даних зумовлена тим, що ця сфера в Україні стрімко розвивається та отримує дедалі більше поширення та визнання, про що свідчить шостий щорічний звіт Open Data Maturity Report 2020 щодо рівня розвитку сфери відкритих даних. Україна посіла 17 місце в рейтингу, продемонструвавши рівень зрілості сфери відкритих даних на рівні 84\%.[1] Однак, враховуючи дані Звіту про проведення моніторингу стану виконання законодавства про доступ до публічної інформації у регіонах України у 2020 році реалізація інфраструктури відкритих даних як основи механізму забезпечення права особи на доступ до інформації наразі потребує врегулювання [2].

Метою даного дослідження є визначення поняття інфраструктури відкритих даних та його аналіз як механізму забезпечення права особи на доступ до публічної інформації у формі відкритих даних. Проблематика забезпечення права особи на доступ до публічної інформації була предметом дослідження вчених-правників: Н. Каменської, О. Нестеренко, С. Тептюк. Зокрема, О. Заярний у свої монографії 
зосереджував увагу на аспекті адміністративних правопорушень у сфері доступу до публічної інформації як виду соціально-правових конфліктів, що існують в інформаційній сфері та деліктологічній складовій державного контролю у сфері доступу до публічної інформації. Однак, в Україні поняття «інфраструктура даних» не $\epsilon$ законодавчо закріпленим та широко дослідженим науковцями, частіше його використання притаманне міжнародній науковій спілноті [3].

Звертаючись до національного законодавства, слід зазначити, що право особи на використання та доступ до публічної інформації закріплено низкою чинних нормативно правових актів, це відповідно загальне право на доступ до інформації визначене статтею $34 \mathrm{Koн-}$ ституції України та положенням Закону України «Про доступ до публічної інформації».[4] [5] Концепція розвитку електронної демократії в Україні визначає, що оприлюднення публічної інформації у формі відкритих даних для вільного використання дасть змогу створити додаткові механізми реалізації права на доступ до інформації, що перебуває у володінні органів влади, додатково забезпечить вільний обіг інформації та можливість іiі подальшого використання для реалізації особистих прав та свобод людини і громадянина [6].

Інфраструктура даних складається 3 масивів даних, організацій, які їх експлуатують та підтримують, а також процесів, політик та інструкцій, що описують використання та управління даними, відповідно всі компоненти мають працювати єдиним механізмом. У своєму дослідженні О. Заярний зазначав, що є необхідність утворення інституту Державного уповноваженого з питань інформації та наділення його спеціальними контрольно-наглядовими повноваженнями, зокрема: призначати перевірки діяльності розпорядників публічної інформації та баз персональних даних як із власної ініціативи, так і за скаргами громадян i юридичних осіб; надавати розпорядникам публічної інформації обов'язкові приписи про усунення виявлених порушень законодавства про доступ до публічної інформації; складати; здійснювати державний моніторинг стану додержання законодавства про доступ до публічної інформації, здійснювати заходи 3 підвищення інформаційної грамотності запитувачів та відповідальних посадових осіб розпорядника публічної інформації.[7]

Згідно Звіту про проведення моніторингу стану виконання законодавства про доступ до публічної інформації у регіонах України у 2020 лише у частини розпорядників належним чином розроблені та затверджені документи, які передбачають чіткий порядок оприлюднення та оновлення інформації у форматі відкритих даних на власному веб-сайті розпорядника i на Єдиному державному порталі 176 
відкритих даних. Нормативні акти скопійовані 3 положень Постанови Кабінету Міністрів № 835 і не передбачають процедури створення, оновлення та оприлюднення наборів відкритих даних, а саме: який відповідальний підрозділ готує той чи інший набір і хто 3 посадових осіб розпорядника відповідає за створення та оновлення відповідного набору.

Налагодження інфраструктури відкритих даних визначено як один 3 основних блоків Методичних рекомендацій підготовлених Державним агентством з питань електронного урядування України з залученням експертів програми «Прозорість та підзвітність у державному управлінні та послугах» [9]. Відповідно зазначено три взаємопов'язаних складники: 1) Нормативний; 2) Організаційний; 3) Технічний. Нормативний складник передбачає впровадження нормативно-правової бази, процедур, які регламентують відкриті дані, перелік наборів даних для оприлюднення, роботу розпорядників, відповідальність, умови використання даних. Національне законодавство визначає загальні принципи та підходи щодо відкритих даних, однак, на рівні органів виконавчої влади, місцевого самоврядування має бути розроблена детальна нормативно правова база. Звіт про проведення моніторингу стану виконання законодавства про доступ до публічної інформації у регіонах України у 2020, визначає важливим компонентом комплексу заходів розробку та затвердження посадових інструкцій, які мають закріплювати відповідальність та вимоги до конкретних осіб у структурі розпорядника. Додатково органам державної влади для виконання безпосередньо передбачених законодавством вимог необхідно виконувати низку вимог організаційного характеру, а саме розпорядникам необхідно забезпечити якісну безперебійну роботу окремих телефонних номерів та електронних скриньок для запитів чи форми на сайті, постійний контроль визначених осіб за надходженням запитів таким способом та їх вчасну реєстрацію.

Технічний складник визначає, що дані повинні бути оприлюднені в чітко визначених форматах, відповідно до стандартів, у певному місці (портал, сайт) та з відповідними строками оновлення. Це комплексний пункт, що включає в себе достатнє фінансове забезпечення, проведення навчальних заходів для відповідальних осіб, дотримання національних та міжнародних стандартів відкритих даних.

Отже, беручи до уваги зазначене вище, «інфраструктура» відкритих даних це не лише описова метафора, це екосистема технологій, процесів та безпосередніх учасників/організацій, необхідних для збору, зберігання, обслуговування, розподілу та (повторного) використання даних різними кінцевими споживачами. Побудова стабільної 
інфраструктури також передбачає розвиток автоматизованих засобів перевірки та ефективний процес контролю якості даних, що може допомогти розпорядниками публікувати дані котрі відповідають стандарту. Впровадження відкритих даних повинне базуватися на дослідженнях та плануванні, оскільки це забезпечить створення працюючої інфраструктури, котра в свою чергу матиме наслідком забезпечення доступу до публічної інформації у формі відкритих даних та допоможе в їх інтеграції до суспільного життя.

\section{Література:}

1. Open Data in Europe 2020 - https://www.europeandataportal.eu/ en/dashboard/2020

2. Звіт про проведення моніторингу стану виконання законодавства про доступ до публічної інформації у регіонах України у 2020 році

3. Principles for strengthening our data infrastructure https://theodi.org/ article/principles-for-strengthening-our-data-infrastructure/

4. Конституція України від 28 червня 1996 р. //Відомості Верховної Ради України. 1996. № 30. Ст. 141.

5. Закон України «Про доступ до публічної інформації» від 13.01.2011 р. // Відомості Верховної Ради України. - 2011. № 32. Ст. 314.

6. Розпорядження Кабінету Міністрів України «Про схвалення Концепції розвитку електронної демократії в Україні та плану заходів щодо її реалізації» від 08.11.2017 р. // Урядовий кур’єр - 2017. № 217.

7. Заярний О. А. : монографія / О. А. Заярний. - Киӥв: Видавничий дім «Гельветика», 2017. - 700 с.

8. Методичні рекомендації Державного агентства 3 питань електронного урядування України 3 залученням експертів програми «Прозорість та підзвітність у державному управлінні та послугах». - 2018. https://data.gov.ua/uploads/files/2018-08-11-104353. 234698 Recomendation.pdf 